\title{
Headship Rate for Population Projection in Johor Bahru
}

\author{
Nurfilzah Mohamad Rawan, ${ }^{1, a}$, Noor Yasmin Zainun ${ }^{1}$, Ahmad Rizal Alias ${ }^{1}$, Izzah Sofea Ibrahim ${ }^{1}$ \\ ${ }^{1}$ Universiti Tun Hussein Onn Malaysia, Faculty of Civil and Environmental Engineering.
}

\begin{abstract}
Headship rate method is used to forecast population for housing demand. This paper presents the application of the method for forecasting population in Johor Bahru metropolitan city in Malaysia. Data used in the projection was based on census data of Johor Bahru provided by Department of Statistic Malaysia for the period of three years. Headship rate can be determined based on the ratio of head of household in age group by its age group total population. Hence, the purpose for this study is to compare a headship rate in Johor Bahru in year 1980, 2000 and 2010. The finding for the study shows that the male headship rate is higher than female headship rate in the 3 years' time. For the male, the highest headship rate identified in age group 50-54 years old while for the female, the highest headship rate identified in age group 65-69 years old.
\end{abstract}

\section{Introduction}

Households play a role as a key to economic and social in society [1]. The changes of the household characteristics, the number and size have huge implications for household formation. To provide strong baselines in projecting future household, the history of household formation and dissolution are important to show how households have evolved over time [1].

Home is a basic need and also as a personal and a family need [2]. As described in the 8th Malaysian Plan in housing provision, the population and economic growth are the two main indicators in the real estate market. Rapid urban development and positive growth in the household give a significant impact in the housing market [3]. Hence, the household structure acts important in the social and economic well-being of families and individuals because the number of households affected the economic resources and the type of relationship that occurs in a household [1].

Ratio of total population in urban areas to total Malaysian citizens is likely increased from 26\% in 1965 to $70 \%$ in 2020 [4]. Johor Bahru state also recorded dramatic increment of the population from 245, 395 in 1980 to 1.35 million in 2010 [5][6]. Besides, Johor Bahru is also noticeable as the main center for migration from elsewhere in this city because of its size and location factor which near to Singapore, a country with the status of First World Country [7]. Therefore, there is a vital need to the government, planners and developers to determine the housing need which can be calculated using headship rate.

According to Datuk Abd Latif bin Bandi, more than $80 \%$ from 46 thousand of affordable houses built in Johor will be concentrated in Johor Bahru due to high demand

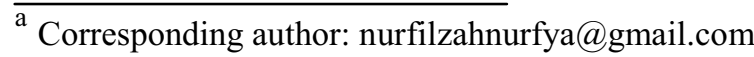

in the region and its strategic location in Iskandar Malaysia [8]. Demand for housing by Singaporean is also occurred because in the past 10 years until June 2013, a total of 9,826 Singaporeans have been approved to own residential properties and shop houses in Johor [9].

Generally, the increment in population and rate of migration cause an increment of housing demand in Johor Bahru [5]. Moreover, the growth in population also changes the headship rate [10]. This is important to show the growth relationship between population and headship rate in term of housing demand.

\subsection{Headship Rate}

Refer to [11], headship rates used to help developer and planners determine the housing needed by household. Besides, headship rates representing the propensity of a certain age in the given age group to form households, and is calculated as the number of household head in the age group divided by the total population of age group [12]. However, [13] defines that the terms of 'headship rate' were basically means the ratio of total household heads to the size of an adult population.

Household formation can be specified into two factors; (1) the size population and age structure and (2) the specific age of headship rate [1]. Age structure is important for an individual in each age group to have a different probability as a households head. Besides, the specific age of headship rate refers to the rate at which the populations in age categories constitute itself into a household [1]

According to Distribution of the Population by Age Groups and Community, Peninsular Malaysia (19571970), the population has been divided into age groups. The productive population accordingly comprises of 
group age among 15 to 64 years old [14]. However, [15] describes that the early group of 0-14 years old is part of the childhood and schooling. The age group among 15-29 years old is the active population which is described in terms of life performance and employment. Besides, the age group of 30-59 years old is adult's population and most of them have been through maturity of working and life. The last age group of 60 years and over began experiencing the aging process [15]. Therefore, this study will conduct and calculate data using headship formulation based on an age distribution with a youngest age group at 15-19 years old and an oldest age group over 80 years old.

\section{Methodologies}

This study used reference manual for the $2 \%$ sample tape of the Population and Housing Census of Malaysia in 1980, 2000 and 2010 [15]. These data were used in calculating headship rates for a project of the population. It was carried out as in figure 1 where the census data were sorted based on the age, gender and population and then the sorted data were used in determining the headship rate.

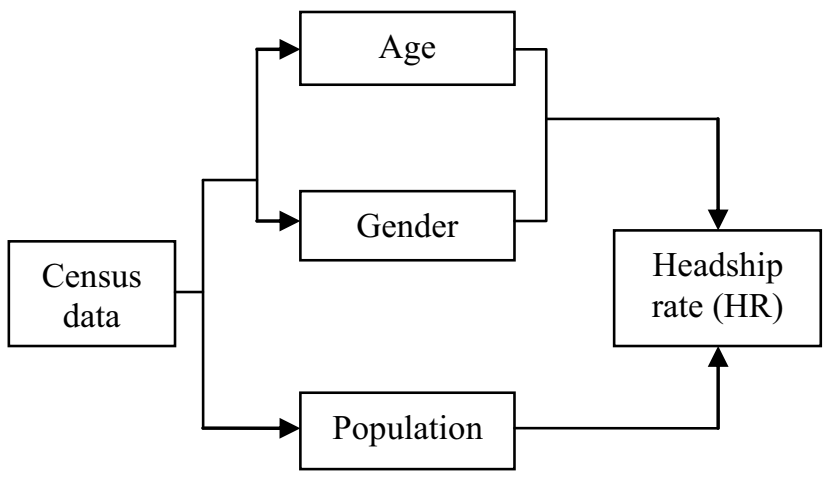

Figure 1. Process of calculating headship

Formula used in calculating the headship is as follow [10]:

$$
H R_{i}=\frac{H H_{i}\left(H_{1}+H_{2}+H_{3} \ldots \ldots H_{i}\right)}{P_{i}\left(P_{1}+P_{2}+P_{3} \ldots \ldots \ldots P_{i}\right)}
$$

Where the number of household's head in the age group and is the total population in the age group. By using equation 1, the headship rates for the district Johor Bahru (1980, 2000 and 2010) are as in table 1 and table 2.

The example for headship rate calculation for the age group 15-19 years old in 1980 using this formula is as below:

$$
\begin{aligned}
H R_{i} & =\frac{5 \text { (head) }}{581 \text { (population) }} \times 100 \\
& =0.8606
\end{aligned}
$$

Table 1. Male headship rate in Johor Bahru (1980, 2000 and 2010)

\begin{tabular}{|l|c|c|c|c|c|c|c|c|c|}
\hline Year & \multicolumn{3}{|c|}{$\mathbf{1 9 8 0}$} & \multicolumn{3}{|c|}{$\mathbf{2 0 0 0}$} & \multicolumn{3}{|c|}{$\mathbf{2 0 1 0}$} \\
\hline Age & Heads & Population & HR & Heads & Population & HR & Heads & Population & HR \\
\hline $15-19$ & 3 & 571 & 0.5254 & 16 & 834 & 1.9185 & 0 & 960 & 0.0000 \\
\hline $20-24$ & 13 & 384 & 3.3854 & 57 & 1168 & 4.8801 & 40 & 1205 & 3.3195 \\
\hline $25-29$ & 11 & 320 & 3.4375 & 62 & 1145 & 5.4148 & 109 & 1427 & 7.6384 \\
\hline $30-34$ & 19 & 244 & 7.7869 & 45 & 947 & 4.7518 & 80 & 1127 & 7.0985 \\
\hline $35-39$ & 10 & 153 & 6.5359 & 40 & 778 & 5.1414 & 81 & 973 & 8.3248 \\
\hline $40-44$ & 21 & 139 & 15.1079 & 50 & 644 & 7.7640 & 106 & 878 & 12.0729 \\
\hline $45-49$ & 7 & 97 & 7.2165 & 50 & 450 & 11.1111 & 84 & 640 & 13.1250 \\
\hline $50-54$ & 15 & 73 & 20.5479 & 52 & 309 & 16.8285 & 85 & 509 & 16.6994 \\
\hline $55-59$ & 20 & 70 & 28.5714 & 43 & 193 & 22.2798 & 70 & 353 & 19.8300 \\
\hline $60-64$ & 15 & 53 & 28.3019 & 47 & 184 & 25.5435 & 59 & 269 & 21.9331 \\
\hline $65-69$ & 15 & 42 & 35.7143 & 27 & 99 & 27.2727 & 24 & 141 & 17.0213 \\
\hline $70-74$ & 7 & 29 & 24.1379 & 17 & 78 & 21.7949 & 26 & 103 & 25.2427 \\
\hline $75-79$ & 2 & 14 & 14.2857 & 7 & 37 & 18.9189 & 13 & 53 & 24.5283 \\
\hline $80+$ & 1 & 8 & 12.5000 & 7 & 42 & 16.6667 & 17 & 86 & 19.7674 \\
\hline
\end{tabular}

Table 2. Female headship rate in Johor Bahru (1980, 2000 and 2010)

\begin{tabular}{|l|c|c|c|c|c|c|c|c|c|}
\hline Year & \multicolumn{3}{|c|}{1980} & \multicolumn{3}{|c|}{ 2000 } & \multicolumn{3}{|c|}{$\mathbf{2 0 1 0}$} \\
\hline Age & Heads & Population & HR & Heads & Population & HR & Heads & Population & HR \\
\hline $15-19$ & 5 & 581 & 0.8606 & 30 & 1004 & 2.9880 & 8 & 980 & 0.8163 \\
\hline $20-24$ & 57 & 321 & 17.7570 & 227 & 1214 & 18.6985 & 184 & 1411 & 13.0404 \\
\hline $25-29$ & 131 & 347 & 37.7522 & 574 & 1251 & 45.8833 & 716 & 1669 & 42.8999 \\
\hline $30-34$ & 142 & 268 & 52.9851 & 714 & 1062 & 67.2316 & 917 & 1334 & 68.7406 \\
\hline $35-39$ & 114 & 196 & 58.1633 & 805 & 988 & 81.4777 & 952 & 1192 & 79.8658 \\
\hline $40-44$ & 97 & 144 & 67.3611 & 634 & 743 & 85.3297 & 837 & 965 & 86.7358 \\
\hline $45-49$ & 81 & 111 & 72.9730 & 502 & 553 & 90.7776 & 719 & 819 & 87.7900 \\
\hline $50-54$ & 61 & 81 & 75.3086 & 340 & 367 & 92.6431 & 512 & 575 & 89.0435 \\
\hline $55-59$ & 38 & 54 & 70.3704 & 186 & 203 & 91.6256 & 352 & 397 & 88.6650 \\
\hline $60-64$ & 37 & 52 & 71.1538 & 180 & 202 & 89.1089 & 273 & 308 & 88.6364 \\
\hline $65-69$ & 30 & 49 & 61.2245 & 70 & 85 & 82.3529 & 127 & 174 & 72.9885 \\
\hline $70-74$ & 15 & 26 & 57.6923 & 49 & 59 & 83.0508 & 106 & 148 & 71.6216 \\
\hline $75-79$ & 7 & 18 & 38.8889 & 18 & 28 & 64.2857 & 60 & 69 & 86.9565 \\
\hline $80+$ & 4 & 12 & 33.3333 & 16 & 28 & 57.1429 & 71 & 109 & 65.1376 \\
\hline
\end{tabular}

\section{Results and Discussion}

The calculated headship rates for the years of 1980, 2000 and 2010 are presented in graphical forms as in figure 2. The headship rates are clustered according to age structure because persons in different age group have different likelihoods of being household heads [12].

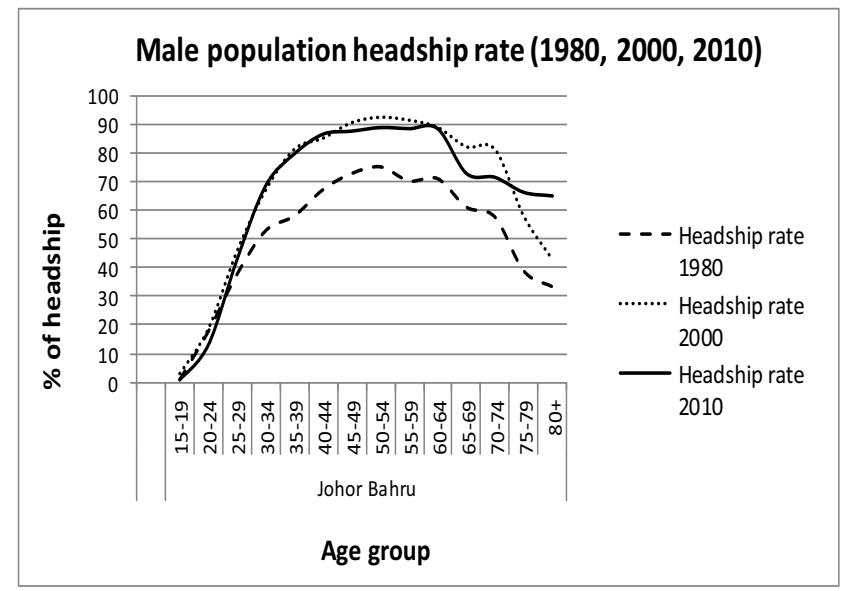

Figure 2. Male population headship rate in year 1980, 2000 and 2010 
Figure 2 shows the age curve of male headship rate. In this figure, the lowest headship rate for 1980, 2000 and 2010 was identified at the early age group of $15-19$ years old with an average value of $1.55 \%$. Meanwhile, the highest rate for the year 1980, 2000 and 2010 were identified in the age group 50-54 years old with an average value of $85.66 \%$. This is in line with a previous study by Andrew D. Paciorek that headship rate was rose rapidly from age 15 to 50 years old.

Besides, the pattern of age curve for male headship rate roughly resembles the male's economic activity rate. Thus, the figure also shows that male becomes the head of household at various ages mostly between 30-74 years old. Meanwhile, as shown in the figure, after age 50 years old, the rate was decreased gradually. The figure also shows the growth in headship rate where the line increase and parallel with increment in population from year 1980 to 2010 where the population is 2260 persons in year 1980, 7787 persons in year 2000 and 10157 persons in 2010 .

(Total of populations: 2 percent sample tape of the Population and Housing Census of Malaysia in year 1980, 2000 and 2010).

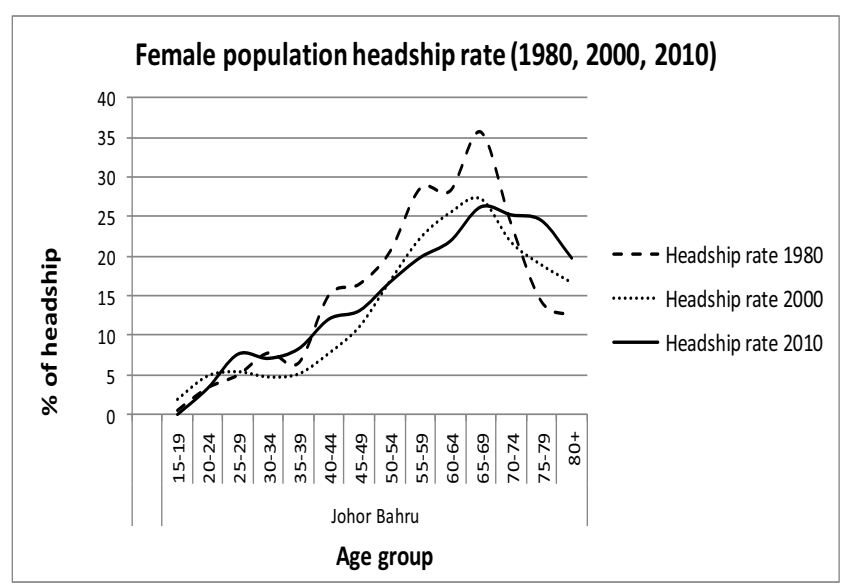

Figure 3. Female population headship rate in year 1980, 2000 and 2010

Figure 3 shows the age specific female headship rate. For a female, the rate of headship is lower than male. In 1980, 2000 and 2010, the highest headship rate identified in the same age group of 65-69 years old and an average value is $29.74 \%$. Meanwhile, the lowest headship rate for 1980, 2000 and 2010 was identified in the early group of 15-19 years old and an average value is $0.81 \%$. Compare to male headship rate, the female headship rate shows the drastic curve. In 1980, the curve decreases dramatically after age 69 year old while in year 2000 and 2010, the curve decrease gradually. This is parallel with previous study by Saw Swee Hock (2010) conclude that age group was experienced aging process and death.

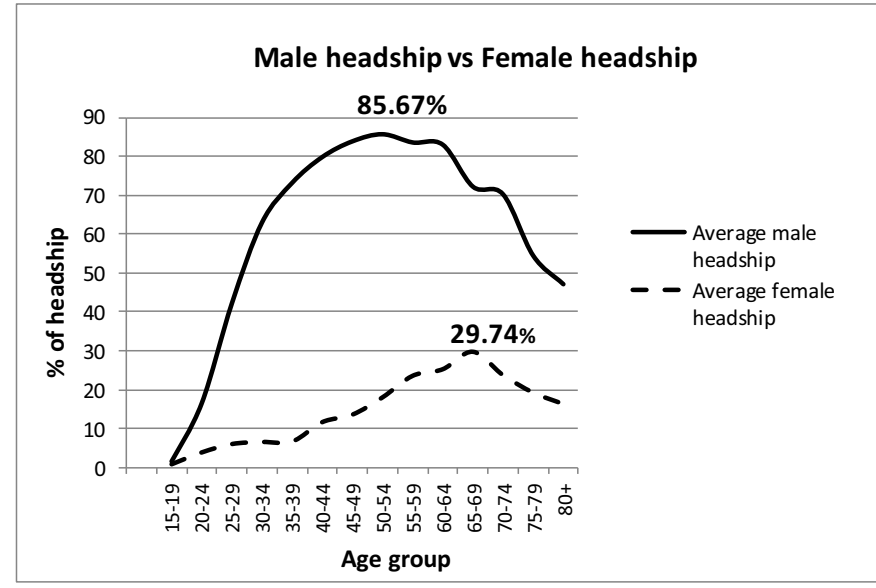

Figure 4. Comparison between male headship and female headship

Figure 4 shows the comparison between male and female headship rate in the year 1980, 2000 and 2010. From the figure, the male headship rate was higher than female headship with an average value of $85.67 \%$ while average female headship is $29.74 \%$.

The comparison is parallel with the book of "Methods of Projecting Households and Families" by United Nation [17], accurately validity the fact that male being a role as a head of their household because their responsibility to make a living.

\section{Conclusion}

In this study, the comparison of headship rate in year 1980, 2000 and 2010 had been identified through headship formulation with the calculation of a ratio of total household heads in the age group to the total population of the age group. The result found that male has higher headship rate than female for year 1980, 2000 and 2010. The highest headship rate for male occurs at age group of 50-54 years old while the highest headship rate for female occurs at age group of 65-69 years old. Both genders show less headship rate in age of 15-19 years old. Therefore, headship formulation was performed well and can be used to forecast population in Johor Bahru in getting housing demand. The data could assist the Ministry of Housing and Local Government in supplying housing according to the demand.

\section{Acknowledgement}

This study is a part of collaboration research between UTHM and SIRIM Berhad. The authors would like to thank Department of Statistic Malaysia for the census data and MOSTI for funding this research under a special grant. 


\section{References}

1. P. H. Hendershott, "Household Formation." National Bureau of Economic Research Working paper Series No. 1390. Massachusetts: Cambridge. June 1984.

2. M. Zulkepli, "Pembangunan Model Penentuan Keperluan Perumahan. Kajian Kes: Johor Bahru, Malaysia." Thesis: Universiti Tun Hussein Onn Malaysia, 2011.

3. Department of Statistic Malaysia. Economy Planning Unit, "8th Malaysia Plan," pp. 295318, 2005 .

4. N. Yasmin Zainun and M Eftekhari, "Forecasting Low-Cost Housing Demand in Urban Area in Malaysia Using ANN." (1): 899902. 2010.

5. Azmi Daud, "Rumah Kos Rendah: Permintaan Melebihi Penawaran Serta Cara Mengatasinya. Kajian Kes: Majlis Perbandaran Johor Bahru," Thesis: Universiti Teknologi Malaysia, 1994.

6. Town and Country Planning Department of Johor, "Johor Development Plan," 2000.

7. A.R. Embong, "Pembandaran dan Kehidupan Bandar di Semenanjung Malaysia," Akademika, vol. 81, no. 2, pp. 23-39, 2011.

8. A.L. Bandi, "Harga rumah naik bukan sebab dibeli warga asing - Nasional - Sinar Harian."Retrieved on November 30, 2015 from www.sinarharian.com.my

9. Bernama, "Johor kawal pemilikan hartanah oleh warga asing - Nasional - Sinar Harian." Retrieved on January 14, 2016 from www.sinarharian.com.my

10. M. Carliner, "Headship Rates and Housing Demand," no. June, pp. 8-12, 2003.

11. Natalia Siniavskaia. "Immigrants in the American Community Survey Table 1 Newly Arrived Immigrants by Age and Region of Origin * Figure 1 Newly Arrived immigrants by Region of Origin , 2008-2010,” 2012.

12. A. D. Paciorek, "Divisions of Research \& Statistics and Monetary Affairs The Long and the Short of Household Formation," 2013.

13. D. Mccue, "Baseline Household Projections for the Next Decade and Beyond," no. March, pp. $1-96,2014$.

14. D. Fernandez, A. Hawley, and S. Predaza, "the Population of Malaysia," C.I.C.R.E.D., pp. 1104, 1975.A. Holmans. New Estimates of Housing Demand and Need in England, 2011 to 2031: submitted to Cambridge Centre for Housing and Planning Research. Paper series no.16. 2013.

15. S.S. Hock. "The population of Malaysia, 2nd Edition". International Typesetters Pte Ltd. 2010.
16. Department of Statistic Malaysia. "Reference Manual for the 2 Per Cent Sample Tape. Population and Housing Census of Malaysia (1980, 2000, 2010).

17. J. Wiley, W. Woytinsky, D. Science et al. "Chapter VI Use of Model Headship Rates", 28(1). 1970 